\title{
The Impacts of Investment in Internal Audit Functions on the Going Concern Opinion for Financially Distressed Firms
}

\author{
FAZLIN ERWINAZ HASSAN \& AMIRUL HAFIZ MOHD NASIR
}

\begin{abstract}
We investigate the effects of internal audit investments on financially distressed firms in Malaysia. Specifically, we examine the impacts of internal audit investments on these firms' going concern opinion. We argue that higher internal audit investments expedite these firms' recoverability by improving their controls and operations. The assurance and consulting activities provided by internal auditors enable these firms to mitigate the material uncertainty of the going concern opinions issued by external auditors. To examine such relationship, we chose 137 firm-year observations of Malaysian financially distressed firms listed on Bursa Malaysia from 2016 to 2018. We ran a logistic regression analysis and found that internal audit investments are negatively and significantly associated with the going concern opinions reported by an external auditor. This result suggests that high internal audit investments reduce the likelihood for an external auditor to issue a going concern opinion. As stated in ISA 570, if recovery plans have no material uncertainty and are sufficient to mitigate the going concern problem (which is argued to be assisted by the internal audit function of the firm), then an external auditor can issue a clean audit report even for firms that are in financial distress. Evidence from this study contributes to our understanding of the importance of investments in internal audit functions and highlights that the assurance and consultation from internal auditors can ensure a careful monitoring of the strategies and operations of firms.
\end{abstract}

Keywords: Internal audit investments; going concern problem; financially distressed firms; Malaysia

\section{INTRODUCTION}

As of 31 July 2018, a total of 24 firms (2.5\% of 909 firms) listed on Bursa Malaysia have been classified as PN17. Anecdotal evidence shows that the percentage of financially distressed firms has reached worrisome levels for shareholders, creditors and regulators, especially during periods of economic downturn (NST 2018). Financially distressed firms are those that need to be restructured or revived in order to maintain their listing status. These firms include those that receive modified opinions with emphasis of matters on going concern paragraph. As economists anticipate a slow economic growth and a highly uncertain external environment, the ability to ensure stable business operations in the future is a priority. Accordingly, we aim to investigate the effect of investment in internal audit functions on the going concern opinions for financially distressed firms.

A going concern opinion is issued when external auditors have material uncertainties regarding the survival of firms within a year. Material uncertainty refers to events or conditions that may trigger auditors to cast doubts on the ability of firms to continue with their business (ISA 570). For financially distressed firms, external auditors have a higher likelihood to issue a going concern opinion given that they need to assess higher uncertainty events for financially distressed firms than for financially healthy firms. However, these material uncertainties can be mitigated with proper recovery plans, such as asset liquidations, borrowing arrangements, debt restructuring, and capital acquisition. If the recovery plans of these firms are coordinated well and satisfy the external auditors' assessment on these firms' ability to continue with their operations, then auditors can issue clean reports to these firms despite being financially distressed.

A going concern opinion is issued to inform shareholders about the financial viability of a firm. This opinion indicates that a firm is financially distressed whether due to its poor liquidity position or increasing loss. In other words, a going concern opinion provides an indication that the firms are approaching bankruptcy and that external auditors are uncertain about the future viability of these firms (Blay \& Geiger 2013). If a firm has a recovery plan and its management is able to execute such plan properly, then a going concern opinion can be avoided. Therefore, to reduce the going concern problems of a financially distressed firm, an external auditor needs to evaluate the strategies, plans, and future actions of its management. Firms should also have effective internal control and efficient operational systems to help external auditors determine their future financial performance and their ability to operate. Therefore, this study aims to highlight the role of internal auditors in corporate governance, especially in the going concern risk assessment of firms. We examine the roles of internal auditors in facilitating going concern risk assessment as part of their assurance and consulting activities in reviewing and analyzing the financial and operating risks of firms.

Previous studies identify several determinants of going concern opinion. For example, a going concern opinion issued by an external auditor is highly related to clients with (1) low liquidity (Dopuch et al. 1987), (2) high operating 
leverage (Mutchler 1985), (3) low profitability (Numan \& Willekens 2011), (4) severe internal control weaknesses (Goh et al. 2013), and (5) high loan default (Carcello et al. 2000). Recent studies in Malaysia suggest that certain factors, such as delisting status (Reza 2019), can influence going concern opinion. However, despite the large number of studies on the determinants of the likelihood for an external auditor to issue going concern opinion, the influence of internal auditors on these opinions remains largely unknown. In this paper, we aim to show how the results of an existing going concern propensity model change when internal audit investment is added as a variable to this model.

This research chooses the Malaysian setting to study the relationship between internal audit investments and going concern problem reported by external auditors for two reasons. First, previous studies that use Malaysian data reveal that not issuing modified opinions about a going concern problem is common in Malaysia. For example, Abdul Wahab et al. (2013) find that only $6.3 \%$ of auditors in Malaysia issue a going concern opinion despite the large number of financially distressed firms they detect. However, recent studies suggest that a larger percentage of financially distressed firms have received going concern reports (e.g., Raza et al. 2019; Osman et al. 2016; Osman et al. 2018), thereby raising the question on whether the low number of financially distressed firms receiving a going concern opinion can be due to other factors, such as the effectiveness of internal audit functions. Second, Malaysia is unique in terms of the availability of data on internal audit investments disclosed by publicly listed companies. According to the Listing Requirements of Bursa Malaysia, all publicly listed companies should disclose the costs they incur for their internal audit functions (Wan-Hussin \& Bamahros 2013). Using the available data, we examine whether effective internal audit functions can influence the recoverability process of financially distressed firms by assessing the risks and control of management recovery plans by internal auditors. As internal auditors are in the best position to comprehend and articulate business operations (Al-Dhamari et al. 2018), it is expected that the assurance and consulting services provided by internal auditors can improve the operational performance and internal control effectiveness of firms, which in turn can lead to an improved financial performance. An effective internal audit function, which is proxied by the amount of internal audit investments, is predicted to increase the probability for firms to receive clean audit opinions and avoid a going concern opinion.

This paper argues that having a better monitoring mechanism, particularly by internal auditors, not only improves controls and financial reporting quality but also increases the effectiveness and efficiency of firm operations. We posit that a higher investment on internal audit activities can reduce the going concern opinions issued by external auditors as a result of improving the internal monitoring mechanisms of firms. Therefore, a higher investment in the internal audit function reduces the risk of receiving a going concern opinion from external auditors.

We collect 137 firm-year observations of financially distressed firms listed on the Bursa Malaysia from 2016 to 2018 to investigate such relationship. The financially distressed firms are identified by using the Zmijewski model, which allows more observations to be tested in the model usage compared to PN17 firms. Financial data are obtained from the Datastream database, whereas internal audit investment and governance-specific data are manually collected from the annual reports of the selected firms. To examine the relationship between internal audit investment and going concern opinion, this study uses the going concern opinion model of Bronson et al. (2009).

Our empirical analysis shows that internal audit investment is negatively related to the likelihood for financially distressed firms to receive a going concern opinion. These results suggest that an internal audit investment can reduce the risk of receiving a going concern opinion from an external auditor, thereby supporting our argument that a higher investment in internal audit function will increase the compliance of internal control and improve the effectiveness and efficiency of a firm's operations, thereby ensuring the success of its recovery plans.

This study offers three contributions to the literature. First, this paper extends agency theory, which posits that the internal audit function not only imposes as a bonding cost to managers but also fulfils a monitoring role. Therefore, an internal auditor helps an external auditor in reducing the risk of financial misstatements while mitigating operational problems. With an increased investment in the internal audit function, more competent and a higher number of internal auditors can be employed to better monitor the internal controls of firms and improve the effectiveness and efficiency of their operations. Second, this paper contributes to the literature on the going concern problem reported by external auditors given that this topic continues to attract considerable interest. This study specifically presents new evidence from Malaysia given that our present understanding of such relationship is limited to developing countries. Third, our findings indicate that firms should consider maintaining their investments in the internal audit function despite facing financial distress to increase assurance on their controls and to improve their operations. We also highlight that the benefits of investing in internal audit outweigh the associated cost for firms, especially the financially distressed ones.

The rest of this paper is organized as follows. Section 2 discusses the going concern problem, internal audit investment, and research hypotheses. Section 3 describes the research methodology. Section 4 illustrates and discusses the results. Section 5 concludes the paper.

\section{LITERATURE REVIEW}

This section reviews two streams of literature. The first stream is related to the going concern problem reported by external auditors, whereas the second stream reviews the effects of internal audit investment. The research hypotheses are then proposed. 


\section{GOING CONCERN OPINION}

Going concern is the most common problem being faced by firms with poor corporate governance, large amount of losses, and operational issues, such as restructuring and dissolution of business (Chan \& Walter 1996; Lim 1997). The decision to issue a modified going concern opinion has to be made by an external auditor when its client needs to pay its outstanding obligations, maintain its business operations after encountering legal proceedings, retain its working capital, or deal with serious internal problems even if such problems are not financial in nature (Arens et al. 2012). In Malaysia, the International Standards on Auditing 570 Going Concern (ISA 570) suggests that auditors should issue an unqualified opinion with a "Material Uncertainty Related to Going Concern" section when the going concern assumption is appropriate in making a financial statement. Before issuing such opinion, external auditors usually learn about the plans of managers to ascertain the strategy of their firms in mitigating the going concern problem. An unqualified modified or qualified audit report with a going concern problem is issued if the external auditor has considerable doubt on the ability of a firm to maintain its viability.

Previous studies show that the issuance of a going concern opinion is affected by several factors, including client, auditor, auditor-client and environmental factors (Carson et al. 2013). Client factors can be categorized into financial (i.e., profitability, liquidity, and leverage) and non-financial items (i.e., corporate governance and strategic initiatives). For nonfinancial items, corporate governance has been identified as one of the main factors that contribute to the issuance of a going concern opinion (Carson et al. 2013), thereby suggesting that an improved corporate governance increases the level of transparency in the financial system and enhancing investor confidence. In addition, Basuony et al. (2014) suggest that agency conflicts can be reduced by using the appropriate corporate governance tools, including the presence of an effective internal auditor.

Other studies have examined the accuracy of a going concern opinion. Geiger and Rama (2006) found that the accuracy of going concern reporting by Big 4 audit firms is higher than that of non-Big 4 firms. Burgland et al. (2018) found that smaller audit firms are less likely to issue going concern opinions to financially distressed firms than Big 4 audit firms. An accurate issuance of a going concern opinion is pertinent to the preservation of stakeholder interest. Shareholders, investors, bankers, suppliers and creditors further decisions will be based in accuracy of the opinion as they are the main users of the audit. Meanwhile, Coelho et al. (2012) show that when firms receive a going concern opinion, investors will change their investments in the firms' competitors. Raza et al. (2018) found that one third of Malaysian delisted firms have received a going concern opinion prior to their delisting status. A going concern opinion may affect the competitiveness of firms in a way that the going concern opinion brings positive news to the competitors' market price. Iskandar et al. (2013) found that CEO duality is positively related to going concern opinion and argue that the CEO, who also serves as the chairman of the company, is not independent enough to resolve the going concern problem of his/her company. Moreover, those firms with a high equity ownership from management and institutional investors are negatively and significantly associated with going concern opinion. In sum, despite evidence on the determinants, accuracy, and consequences related to going concern opinion reporting, the relationship between internal audit investment and going concern reporting has been supported by minimal empirical evidence. Therefore, we further examine the influence of internal audit function, as another governance-specific variable, on going concern opinion.

\section{INTERNAL AUDITING}

The second stream of literature reviewed in this study is related to the internal audit function. Many studies have focused on outsourcing the internal audit function (e.g., Barr-Pulliam 2016; Abdolmohammadi 2013; Anderson et al. 2012; Carey et al. 2006; Ismael 2018; Davidson et al. 2013; Bartlett et al. 2015). For instance, Barr-Pulliam (2016) shows that approximately $38 \%$ of organizations around the world have outsourced their internal auditing functions. Compared with public and private companies, financial institutions, publicly traded firms, and non-profit organizations are more likely to outsource their internal audit functions. Abdolmohammadi (2013) found a positive and significant association between audit committee involvement and outsourcing. Outsourcing is also found to be negatively associated with the size of internal audit function (Anderson et al. 2012; Carey et al. 2006). Other studies on the formation of an internal audit function have focused on its determinants. Ismael (2018) investigated those factors that influence the voluntary use of internal audit. By using a sample of 332 UK non-financial companies listed on the London Stock Exchange Main Market, they found that those factors associated with the formation of an internal audit function include firm size, risks, agency problem, and effective audit committee. With regard to the relationship between external auditor and internal audit function, Davidson et al. (2013) found that an external auditor neither relies on in-house nor outsource its internal audit function. By contrast, Bartlett et al. (2015) found that outsourcing an internal audit function is related to a greater reliance from an external auditor. Therefore, internal auditing affects the work of external auditors, including their judgment of the going concern problem.

Apart from its outsourcing, other studies have focused on the determinants and effectiveness of the internal audit function (Narayanaswamy et al. 2019; Goodwin-Stewart \& Kent 2006), its costs (Carcello et al. 2005; Barua et al. 2010), and its investment in Malaysia (Omer \& Al-Qadasi 2020; Al-Dhamari et al. 2018; Wan-Hussin \& Bamahros 2013). Previous studies identify client size, level of commitment to risk management, capital market size, and range of audit tasks as the 
determinants of this function (e.g., Goodwin-Stewart \& Kent 2006; Gronewold \& Heerlein 2009). Narayanaswamy et al. (2019) suggest that size, publicly listed companies, direct chief internal audit reporting (CAE) to audit committee, and total number of years of CAE are all associated with the extent of support for the internal audit function. By contrast, both Barua et al. (2010) and Carcello et al. (2005) review the effect of investment in internal audit in the US and found that such investment is significantly and positively related to company size, industry types, leverage, inventory, cash flows from operations, and number of audit committee meetings yet is negatively related to the presence of auditing experts in the audit committee and the average tenure of audit committee members (Barua et al. 2010; Carcello et al. 2005). Some studies in Malaysia have also examined internal audit investment. Omer and Al-Qadasi (2020) suggest that family firms invest less in the internal audit function. Meanwhile, Al-Dhamari et al. (2018) document the effects of audit committee characteristics on internal audit investment by using data from 96 companies listed on Bursa Malaysia from 2012 to 2014 and found that audit committee meeting is positively and significantly associated with internal audit investment. Wan-Hussin and Bamahros (2013) found a negative and significant relationship between internal audit function and external audit reporting delay. In sum, given the importance of investing in internal audit, examining the relationship between such investment and the going concern status of firms can enrich the auditing literature.

We also review some studies on the effects of internal audit practices. For example, Archambeault et al. (2008) found that internal audit disclosures promote investors' understanding of the internal audit function in governance. Breger et al. (2020) argued that external auditors have increased their reliance on internal auditing since the Sarbanes-Oxley Act 2002 and found that these auditors are willing to rely on internal audit work if they adhere to the standards on internal auditing practices issued by the Institute of Internal Auditors (IIA). Cular et al. (2020) examined the reliance of external auditors on the internal audit function and found that if such function provides consulting services on enterprise risk management, then the reliance of external auditors will only increase when the audit committee effectiveness is strengthened. Both Breger et al. (2020) and Cular et al. (2020) studies were examine in an environment where external auditors are no longer allowed to provide internal audit services to their audit clients. The regulation applies both in the US Sarbanes Oxley Act (2002) and Malaysia (2008). In sum, despite evidence supporting the reliance of external auditors on internal audit work, no empirical evidence explicitly links investment in internal audit to the likelihood for external auditors to issue a going concern opinion.

\section{HYPOTHESIS DEVELOPMENT}

IIA (2011) states that the internal audit function is critical for reviewing and assessing internal controls, risk management, and corporate governance. This function assures and consults firm managers to follow the internal policies and regulations and to improve the efficiency and effectiveness of their operations. Firms are exposed to the risk of non-compliance to regulations, inaccurate financial reporting, and inefficient operations due to their ineffective internal audit functions. For example, in terms of financial statement accuracy, Barua et al. (2010) argued that the internal audit function can ensure the integrity and quality of financial reporting. Theoretically, internal audit can be described as a bonding cost incurred by management in reducing their agency problems, such as adverse selection and moral hazards. Internal auditors are also expected to monitor the agency problems emerging at the management level. By reducing agency problems, internal auditors not only ensure compliance of regulation, standards, and policies but also, according to Al-Dhamari et al. (2018), are in the best position to comprehend and articulate business operations.

This study argues that a greater investment in the internal audit function can reduce the likelihood for firms to receive a going concern opinion from external auditors. Specifically, internal audit is an important function of the internal monitoring mechanism in corporate governance, especially in ensuring the compliance and effectiveness of internal controls and the efficiency of operations. A greater investment in the internal audit function also corresponds to more competent internal audit departments that help firms (on activities and advice from experts) establish stronger controls over their financial reporting and improve their operations. Goh et al. (2013) suggested that the material weaknesses in internal control increase the likelihood for a firm to receive a going concern opinion because having a weak internal control increases the difficulties faced by an external auditor in determining the future financial performance and ability of firms to operate. Prawitt et al. (2009) also found that a well-funded internal audit function can provide additional resources that help the internal audit department in hiring and retaining highly competent personnel. According to Breger et al. (2020), an external auditor chooses to rely on internal audit works if the internal auditors are highly competent and objective. They also show that the compliance of internal audit to IIA standards influences the reliance decision of external auditors. In this paper, we examine whether internal audit investments affect the likelihood for a firm to receive a going concern opinion from an external auditor. Given that internal audit functions become more competent and objective when internal auditors have a sufficient amount of resources, we contend that a greater investment in these functions improves the ability of these auditors to ensure compliance, effective and efficient internal control systems, and operations. As a result, an effective internal audit function reduces the risk of receiving a going concern opinion from external auditors, especially for financially distressed firms. We then hypothesize the following: 
$\mathrm{H}_{1}$ : An internal audit investment is negatively related to the likelihood of issuing a going concern opinion to financially distressed firms.

\section{RESEARCH DESIGN}

\section{DATA AND SAMPLE SELECTION}

This study tests the above hypothesis by selecting financially distressed firms listed on the Bursa Malaysia from 2016 to 2018. We identify financially distressed firms based on the financial distress prediction model of Zmijewski (1984). Specifically, Zmijewski (1984) argued that firms are in distress if the probability of financial distress model is greater than 0 . The required data were collected from two sources. On the one hand, the audit opinion and internal audit investment data were extracted from the annual reports of the selected firms. All manually collected accounting data are not commercially available. On the other hand, the financial accounting data were collected from the Datastream database, which is commercially available. Our final sample includes 137 financially distressed firm-year observations, of which 53 firms have received a going concern opinion and the others have received clean reports.

\section{EMPIRICAL MODEL}

A cross-sectional model was adapted from Bronson et al. (2009). While Bronson et al. (2009) focused on the effects of audit committees on going concern reporting, this study focuses on the effects of internal audit investments. A new variable, LN_IAI, was incorporated into the model to analyse the effect of internal audit investments on the likelihood of receiving a going concern opinion. LN_IAI is represented by the natural log of internal audit investment. The dependent variable is the likelihood of going concern opinion (GC), a dummy variable that takes a value of 1 for firms with a going concern opinion and 0 for other firms. We tested our hypothesis by using the following logistic regression model to check the relationship between internal audit investment and the likelihood of receiving a going concern opinion:

$\mathrm{GC}=\beta_{0}+\beta_{1} \mathrm{LN} \_\mathrm{IAI}+\beta_{2} \mathrm{ACIND}+\beta_{3} \mathrm{ACMEET}+\beta_{4} \mathrm{ACFIN}+\beta_{5} \mathrm{LNTA}+\beta_{6} \mathrm{BIG} 4+\beta_{7} \mathrm{AUDITLAG}+\beta_{8} \mathrm{PRIOROPN}+$ $\beta_{9} \mathrm{ZMISCORE}+\bar{\beta}_{10} \mathrm{INDUSTRY}+\varepsilon$

We controlled for several variables that influence the likelihood for an external auditor to issue a going concern opinion. Previous studies indicate that a going concern opinion is positively associated with audit committee independence (Bronson et al., 2009). Therefore, we controlled for the percentage of audit committee independence. We also controlled for other corporate governance characteristics, such as the percentage of meetings attended and the number of audit committee members with financial expertise. Other control variables include audit quality (BIG4), delay in audit report issuance (AUDITLAG), issuance of a prior going-concern report (PRIOROPN), firm size (LNTA), and financial condition (ZMI). BIG4 takes a value of 1 if the firm is being audited by a Big 4 audit firm and takes a value of 0 otherwise, AUDITLAG represents days between the year end and the audit report date, PRIOROPN takes a value of 1 if a going concern report is issued in the previous year and takes a value of 0 otherwise, LNTA is the natural log of total assets, and ZMI is Zmijewski's (1984) scores of financial condition index.

\section{RESULTS AND DISCUSSION}

\section{DESCRIPTIVE AND UNIVARIATE RESULTS}

Table 1 presents the overall descriptive statistics of our sample. Approximately $38.7 \%$ (53 out of 137) of the financially distressed firms in our sample have received a going concern opinion. The mean, minimum, and maximum values for internal audit investment (IAI) for our entire sample are RM220,000, RM5,100, and RM5,800,000, respectively. For governance characteristics, the mean and minimum values for audit committee independence for all firms are $87 \%$ and $66.7 \%$, respectively. The audit committees in our sample conduct an average of 5 meetings every year with a minimum and maximum of 1 and 11 meetings, respectively. At least a quarter of the audit committee members of each firm has financial expertise. Big 4 (BIG4) audit firms audit $63.5 \%$ of the sample, and the average time of audit or audit lag (AUDITLAG) for the sample is 107 days. On average, $19.7 \%$ of our sample has received a going concern opinion in their prior audit reports (PRIOR). The average total assets (TA) of our sample is RM1,470,000,000. 
TABLE 1. Overall descriptive analysis

\begin{tabular}{lcccccc}
\hline \multicolumn{1}{c}{ Variables } & $\mathrm{n}$ & Mean & Std. Dev. & Min & Median & Max \\
\hline GC & 137 & 0.387 & 0.489 & 0 & 0 & 1 \\
IAI & 137 & 220,000 & 690,000 & 5,100 & 50,000 & $5,800,000$ \\
LN_IAI & 137 & 10.992 & 1.390 & 8.531 & 10.820 & 15.580 \\
ACIND & 137 & 0.886 & 0.155 & 0.667 & 1.000 & 1.000 \\
ACMEET & 137 & 5.153 & 1.283 & 1.000 & 5.000 & 11.000 \\
ACFE & 137 & 0.417 & 0.152 & 0.250 & 0.333 & 1.000 \\
BIG4 & 137 & 0.635 & 0.483 & 0.000 & 1.000 & 1.000 \\
AUDITLAG & 137 & 107 & 38 & 38 & 104 & 480 \\
PRIOR & 137 & 0.197 & 0.399 & 0.000 & 0.000 & 1.000 \\
TA('000) & 137 & $1,500,000$ & $5,200,000$ & 26 & 410,000 & $44,000,000$ \\
LNTA & 137 & 19.382 & 2.409 & 10.166 & 19.820 & 24.504 \\
ZMI & 137 & $1,400.000$ & $16,000.000$ & 0.005 & 0.826 & $80,000.000$ \\
INDUSTRY & 137 & 6.183 & 4.090 & 1.000 & 5.000 & 15.000 \\
\hline
\end{tabular}

Note: GC is a dummy variable, which takes the value of 1 for firms with going concern opinion and 0 otherwise; IAI is the amount of internal audit investment; LN_IAI represents the natural log of internal audit investment; ACIND represents the proportion independent member of each audit committee; ACMEET is the number of audit committee meeting for the year; ACFE represents the number of financial expertise in among members of each audit committee; BIG4 is 1 if the firms being audited by Big four audit firm and 0 otherwise; AUDITLAG is days between the year end and the audit report date; PRIOROPN is 1 if going concern report in prior year and 0 otherwise; TA is the amount of total assets of the firms; LNTA is the natural log of total assets; ZMI is Zmijewski's (1984) scores of financial condition index (Firms with the X value more than 0 are predicted in financial distress); INDUSTRY is the firm industry.

Table 2 presents the descriptive statistics of the samples by going concern opinion. The mean, minimum, and maximum IAI for firms with a going concern problem are RM62,000, RM7,150, and RM810,031, respectively. The average IAI for firms that receive a going concern opinion is lower (approximately RM62,000) than that of firms with clean reports (approximately RM320,000), thereby suggesting that the firms that receive a going concern opinion allocate less resources to their internal audit investment compared with their clean report counterparts. However, these two groups of firms do not significantly differ in their corporate governance characteristics. For example, $41.7 \%$ of the audit committee members in both groups of firms have financial expertise. In line with our expectations, 52 out of 53 (98\%) going concern firms have received a going concern opinion from BIG4 auditors, whereas more than half of the clean report firms have been audited by non-BIG4 auditors. Among the 53 firms that have received a going concern opinion, $41.5 \%$ or 22 firms have received a going concern opinion in the previous year. These firms also take a longer time to be issued an audit report (119 days) compared with their clean report counterparts (99 days).

Table 3 presents the Pearson correlation matrix. As expected, LN_IAI is negative and significantly associated with going concern opinion reporting. The univariate analysis supports our hypothesis on the relationship between internal audit investment and external auditor going concern reporting. For the control variables, we find a positive and significant relationship between BIG4 and the dependent variable (with a correlation coefficient of 0.571 ), thereby suggesting that Big 4 audit firms are more likely to report a going concern opinion than non-Big 4 ones. The correlation between AUDITLAG and going concern opinion is also significant with a coefficient of 0.259 , thereby suggesting that auditors may need more time to issue a going concern opinion when auditing financially distressed firms. The highly negative relationship between LNTA and the likelihood of receiving a going concern opinion suggests that the likelihood of receiving such opinion is associated with smaller firms than with larger firms. However, we do not find any significant relationship between governance-specific variables and going concern opinion. The correlation matrix analysis also reveals the absence of any multicollinearity problems due to the low correlation coefficients.

TABLE 2. Descriptive by going concern opinion

\begin{tabular}{|c|c|c|c|c|c|c|}
\hline \multirow[b]{2}{*}{ Variable } & \multicolumn{3}{|c|}{$\begin{array}{l}\text { Going concern opinion } \\
\qquad(\mathrm{n}=53)\end{array}$} & \multicolumn{3}{|c|}{$\begin{array}{l}\text { Non-going concern opinion } \\
\qquad(\mathrm{n}=84)\end{array}$} \\
\hline & Mean & Std. Dev. & Median & Mean & Std. Dev. & Median \\
\hline IAI & 62,000 & 110,000 & 40,000 & 320,000 & 860,000 & 69,000 \\
\hline LN_IAI & 10.478 & 0.954 & 10.597 & 11.316 & 1.523 & 11.144 \\
\hline ACIND & 0.895 & 0.150 & 1.000 & 0.880 & 0.159 & 1.000 \\
\hline
\end{tabular}




\begin{tabular}{|c|c|c|c|c|c|c|}
\hline ACMEET & 5.245 & 1.175 & 5.000 & 5.095 & 1.350 & 5.000 \\
\hline ACFE & 0.417 & 0.148 & 0.333 & 0.417 & 0.155 & 0.333 \\
\hline BIG4 & 0.981 & 0.137 & & 0.417 & 0.496 & \\
\hline AUDITLAG & 119.094 & 56.170 & 112.000 & 99.000 & 14.787 & 102.000 \\
\hline PRIOR & 0.415 & 0.498 & & 0.060 & 0.238 & \\
\hline TA ('000) & 460,000 & 560,000 & 290,000 & $2,100,000$ & $6,600,000$ & 470,000 \\
\hline LNTA & 18.784 & 2.417 & 19.501 & 19.759 & 2.340 & 19.979 \\
\hline ZMI & 62,000 & 110,000 & 40,000 & 320,000 & 860,000 & 69,000 \\
\hline INDUSTRY & 5.566 & 4.000 & 3.925 & 6.571 & 8.000 & 4.166 \\
\hline
\end{tabular}

Note: This table reports the mean, standard deviation and median for all variables used in the analyses by going concern opinion. Note: IAI is the amount of internal audit investment; LN_IAI represents the natural log of internal audit investment; ACIND represents the proportion independent member of each audit committee; ACMEET is the number of audit committee meeting for the year; ACFE represents the number of financial expertise in among members of each audit committee; BIG4 is 1 if the firms being audited by Big four audit firm and 0 otherwise; AUDITLAG is days between the year end and the audit report date; PRIOR is 1 if going concern report in prior year and 0 otherwise; TA is the amount of total assets of the firms; LNTA is the natural log of total assets; ZMI is Zmijewski's (1984) scores of financial condition index (Firms with the $\mathrm{X}$ value more than 0 are predicted in financial distress); INDUSTRY is the firm industry.

\section{MULTIVARIATE ANALYSIS}

Table 4 presents the logistic regression results. The model has a chi-square of $118.23(\mathrm{p}>0.01)$, thereby indicating its good fit to the data. Meanwhile, the Nagelkerke R2, Cox and Snell Pseudo-R2, and McFadden R2 values suggest that 78.5\%, $57.8 \%$, and $64.7 \%$ of the changes in the dependent variable can be explained by our model, respectively. Consistent with the univariate test results, Table 4 shows that internal audit investment is negatively and significantly related to the likelihood for external auditors to issue a going concern opinion $(\beta=-1.168, p<0.01)$, thereby supporting our hypothesis that internal audit investments influence the going concern problem reported by external auditors for financially distressed firms. This result also supports our argument that an effective internal audit function facilitates the recoverability of firms through the assurance and consulting services provided by internal auditors. These auditors not only assess the financial distress risk faced by firms but also ensures the effectiveness of their internal control and operational activities, which later translate into improved financial performance and reduce the likelihood of the going concern opinions reported by an external auditor. These results are also in line with those of Al-Dhamari et al. (2018), who argued that which internal auditors not only ensure compliance of regulation, standards, and policies but are also in the best position to comprehend and articulate the business operations of firms.

Table 4 presents the results for the control yariables, namely, BIG4, AUDITLAG, PRIOR, LNTA, and ZMI. Among these variables, only BIG4, AUDITLAG, and PRIOR are significantly and positively related to going concern opinion. The BIG4 and AUDITLAG coefficients of 6.560 and 0.046 are positive and significant at the 0.01 and 0.1 levels, whereas the PRIOR coefficient of 2.642 is positive and significant at the 0.05 level. Therefore, a firm faces a higher probability of receiving a going concern opinion if audited by big firms or if issued a going concern opinion in its previous audit. By contrast, all our governance-specific variables are not significantly related to going concern opinion, whereas LNTA is negatively yet insignificantly related to going concern opinion 
TABLE 3. Pearson (Spearman) correlation analysis

\begin{tabular}{|c|c|c|c|c|c|c|c|c|c|c|c|c|c|}
\hline & $\mathrm{GC}$ & IAI & LN_IAI & ACIND & ACMEET & ACFE & BIG4 & AUDLAG & PRIOR & TA ('000) & LNTA & ZMI & INDUSTRY \\
\hline $\mathrm{GC}$ & 1 & $-0.277^{*}$ & $-0.277^{*}$ & 0.052 & 0.138 & -0.002 & $0.571 *$ & $0.351^{*}$ & $0.435^{*}$ & $-0.240 *$ & $-0.240^{*}$ & $0.302 *$ & -0.112 \\
\hline IAI & $-0.181 *$ & 1 & $1.000 *$ & -0.092 & 0.044 & -0.048 & $0.178 *$ & -0.074 & $-0.187^{*}$ & $0.615^{*}$ & $0.615^{*}$ & $-0.328^{*}$ & -0.054 \\
\hline LN_IAI & $-0.295^{*}$ & $0.638^{*}$ & 1 & -0.092 & 0.044 & -0.048 & $0.178^{*}$ & -0.074 & $-0.187^{*}$ & $0.615^{*}$ & $0.615^{*}$ & $-0.328^{*}$ & -0.054 \\
\hline ACIND & 0.046 & 0.070 & -0.064 & 1 & -0.133 & -0.113 & -0.118 & 0.083 & 0.019 & -0.064 & -0.064 & 0.043 & $-0.205^{*}$ \\
\hline ACMEET & 0.057 & -0.019 & 0.059 & $-0.170^{*}$ & 1 & -0.062 & 0.087 & 0.085 & -0.092 & -0.004 & -0.004 & -0.035 & 0.023 \\
\hline ACFE & 0.000 & 0.026 & 0.014 & -0.119 & -0.016 & 1 & 0.045 & -0.057 & 0.031 & -0.042 & -0.042 & 0.053 & -0.019 \\
\hline BIG4 & $0.571^{*}$ & 0.119 & $0.178^{*}$ & -0.120 & 0.044 & 0.050 & 1 & & $0.185^{*}$ & $0.174 *$ & $0.174 *$ & 0.085 & -0.058 \\
\hline AUDITLAG & $0.259 *$ & -0.095 & -0.163 & 0.095 & $-0.200 *$ & -0.074 & 0.157 & & 0.146 & -0.101 & -0.101 & 0.139 & 0.011 \\
\hline PRIOR & $0.435^{*}$ & -0.125 & $-0.216^{*}$ & 0.020 & -0.131 & 0.030 & $0.185^{*}$ & $0.196^{*}$ & 1 & $-0.244^{*}$ & $-0.244 *$ & $0.310^{*}$ & -0.163 \\
\hline TA ('000) & -0.153 & $0.659^{*}$ & $0.510^{*}$ & 0.083 & -0.052 & 0.004 & 0.119 & -0.077 & -0.103 & 1 & $1.0000^{*}$ & $-0.366^{*}$ & 0.011 \\
\hline LNTA & $-0.198^{*}$ & $0.336^{*}$ & $0.534 *$ & -0.041 & 0.068 & -0.098 & & $-0.171^{*}$ & $-0.328^{*}$ & $0.385^{*}$ & 1 & $-0.366^{*}$ & 0.011 \\
\hline ZMI & -0.070 & -0.027 & -0.095 & 0.065 & -0.149 & -0.036 & 0.060 & 0.005 & -0.037 & -0.019 & -0.003 & 1 & 0.032 \\
\hline INDUSTRY & -0.120 & -0.090 & -0.052 & $-0.198^{*}$ & 0.013 & -0.014 & -0.044 & -0.057 & -0.162 & -0.074 & 0.045 & 0.035 & 1 \\
\hline
\end{tabular}

Note: *correlation is significant at the 0.05 level (two-tailed). GC is a dummy variable, which takes the value of 1 for firms with going concern opinion and 0 otherwise; IAI is the amount of internal audit investment; LN_IAI represents the natural log of internal audit investment; ACIND represents the proportion independent member of each audit committee; ACMEET is the number of audit committee meeting for the year; ACFE represents the number of financial expertise in among members of each audit committee; BIG4 is 1 if the firms being audited by Big four audit firm and 0 otherwise; AUDITLAG is days between the year end and the audit report date; PRIOR is 1 if going concern report in prior year and 0 otherwise; TA is the amount of total assets of the firms; LNTA is the natural log of total assets; ZMI is Zmijewski's (1984) scores of financial condition index (Firms with the X value more than 0 are predicted in financial distress); INDUSTRY is the firm industry. 
TABLE 4. Main results (Logistic analysis)

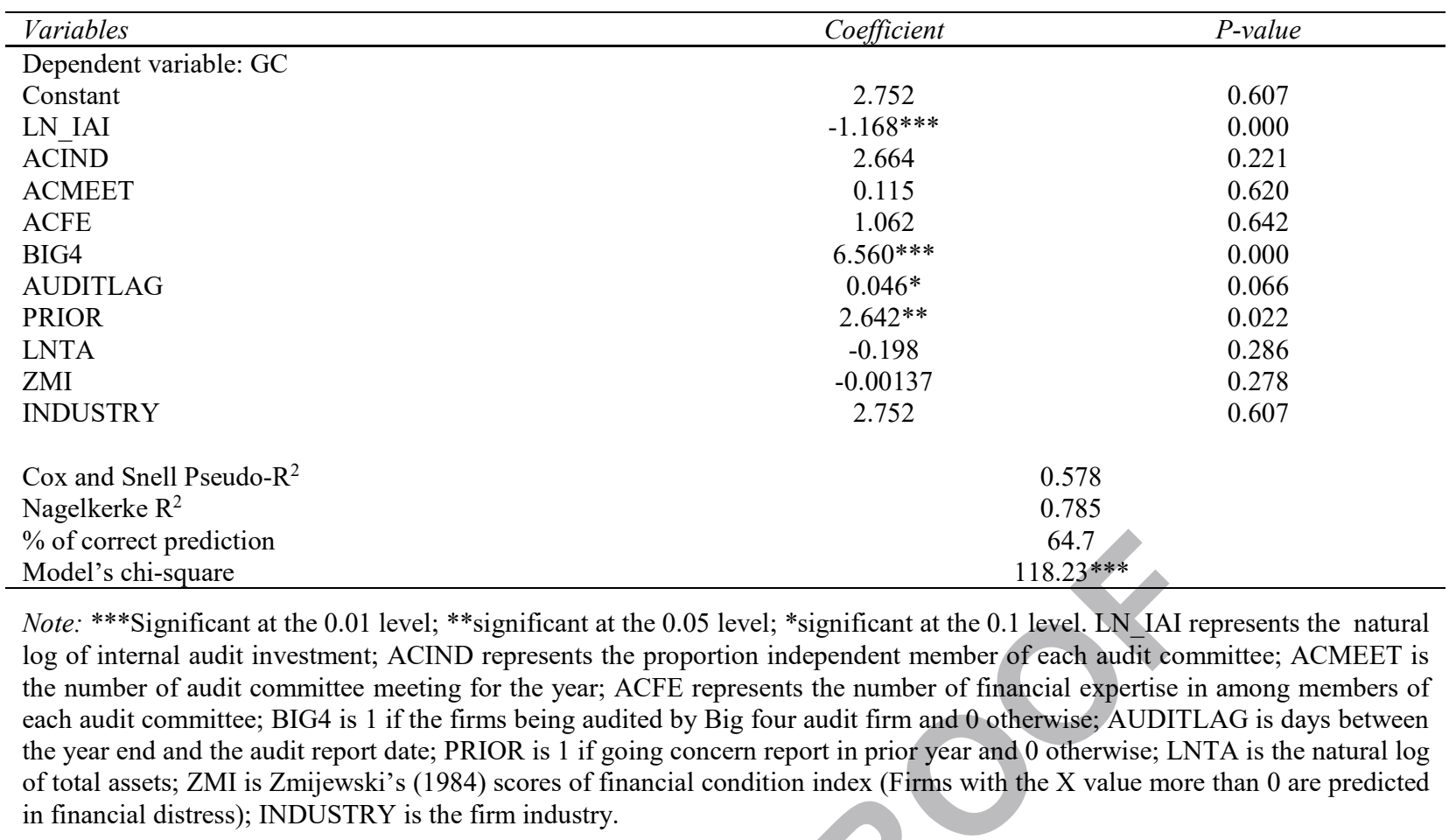

\section{ROBUSTNESS TEST}

Despite our small sample, we discover that internal audit investment reduces the likelihood of receiving a going concern opinion from an external auditor. To test the credibility of our findings, we perform a logistic regression analysis by using an alternative proxy for financially distressed firms. We choose those observations with a net loss position from our sample as another proxy for financially distressed firms. The robustness test results are consistent with the main findings reported earlier. Table 5 below presents the robustness test results.

TABLE 5. Robustness test

\begin{tabular}{lcc}
\hline Variables & Coefficient & P-value \\
\hline Dependent variable: GC & & 0.781 \\
Constant & 1.984 & 0.007 \\
LN_IAI & $-1.255^{* * *}$ & 0.112 \\
ACIND & 5.208 & 0.663 \\
ACMEET & -0.152 & 0.538 \\
ACFE & 2.065 & 0.000 \\
BIG4 & $7.182^{* * *}$ & 0.307 \\
AUDITLAG & 0.032 & 0.157 \\
PRIOR & 1.880 & 0.649 \\
LNTA & -0.143 & 0.349 \\
ZMI & -0.001 & 0.781 \\
INDUSTRY & 1.984 & \\
Cox and Snell Pseudo-R & & \\
Nagelkerke R & & \\
\% of correct prediction & & 0.586 \\
Model's chi-square & & 0.781 \\
\hline
\end{tabular}

Note: ***Significant at the 0.01 level; **significant at the 0.05 level; *significant at the 0.1 level. LN_IAI represents the natural $\log$ of internal audit investment; ACIND represents the proportion independent member of each audit committee; ACMEET is the number of audit committee meeting for the year; ACFE represents the number of financial expertise in among members of each audit committee; BIG4 is 1 if the firms being audited by Big four audit firm and 0 otherwise; AUDITLAG is days between the year end and the audit report date; PRIOR is 1 if going concern report in prior year and 0 otherwise; LNTA is the natural log of total assets; ZMI is Zmijewski's (1984) scores of financial condition index (Firms with the X value more than 0 are predicted in financial distress); INDUSTRY is the firm industry. 


\section{CONCLUSION}

This paper examines the relationship between internal audit investments and going concern problem as reported by external auditors for financially distressed firms in Malaysia with an aim to show how a going concern opinion changes when internal audit investment is added as a variable to our model. By using 137 observations of financially distressed firms listed on Bursa Malaysia from 2016 to 2018, our main results suggest that internal audit investment is negatively and significantly related to the going concern opinion reported by external auditors. In other words, internal audit contributes to the recoverability process of firms by improving their controls and operations, which in turn reduces the probability for external auditors to issue a going concern opinion. To enhance the credibility of our findings, we conduct a robustness test by using alternative measures of financial distress. Our robustness test results are consistent with our main analysis results.

Our findings provide important implications for managers and internal auditors. On the one hand, managers must at least maintain their investment in internal audit to reduce their risk of receiving a going concern opinion from external auditors. Reducing such investment may also deteriorate the conditions of their firms, and the controls, effectiveness, and efficiency of their operations need to be in place especially during periods of financial distress. Instead of reducing their internal audit investments, managers should focus on their strategies and recovery plans while allowing internal auditors to focus on their controls, operational efficiency, and effectiveness. These results imply that internal auditors play a crucial role for financially distressed firms by ensuring that the strategies and plans of these firms are carefully executed and closely monitored.

This study has several limitations. To overcome these limitations, we identify several avenues for future research. First, our findings may not be generalizable to all listed firms because we only focus on financially distressed firms listed on Bursa Malaysia. Future studies may consider using a larger sample that comprise all firms listed on Bursa Malaysia and utilize a panel data research design that may to yield different results. Second, given that we are only using Zmijewski's (1984) scores of financial condition index and net loss position, future studies should consider other proxies for financially distressed firms. Third, this study does not consider the extent of an external auditor's reliance on internal auditor work as a control variable. Therefore, future research should control for the level of external auditor reliance if such data are available. Finally, future studies should compare the tendency for Big 4 and non-Big 4 firms and their accuracy in issuing going concern opinions.

\section{ACKNOWLEDGEMENT}

The authors acknowledge the support of research funding from Kursi Cemerlang Yayasan Tun Ismail Mohamed Ali (YTIUKM) in conducting this research (Project code: EP-2020-008).

\section{REFERENCES}

Abdolmohammadi, M. 2013. Correlates of co-sourcing/outsourcing of internal audit activities. Auditing: A Journal of Practice \& Theory 32 (3): 69-85.

Abdul Wahab, E. A., Mat Zain, M. \& Abdul Rahman, R. 2013. Political connections, fees paid to auditors and auditor independence in Malaysia: Evidence from going concern audit opinion. International Journal of Accounting, Auditing and Performance Evaluation 9(2): 153-183.

Al-Dhamari, R., Almagdoub, A., \& Al-Gamrh, B. 2018. Are audit committee characteristics important to the internal audit budget in Malaysian firms. Contaduría y administración 63(2): 947-969.

Anderson, U.L., Christ, M.H., Johnstone, K.M. \& Rittenberg, L.E. 2012. A post-SOX examination of factors associated with the size of internal audit functions. Accounting Horizons 26 (2): 167-91.

Arens, A.A., Elder, R.J. \& Mark, B. 2012. Auditing and Assurance Services: An Integrated Approach. Boston: Prentice Hall.

Archambeault, D.S., DeZoort, F.T. \& Holt, T.P. 2008. The need for an internal auditor report to external stakeholders to improve governance transparency. Accounting Horizons 22(4): 375-388.

Barr-Pulliam, D. 2016. Engaging Third Parties for Internal Audit Activities. The Institute of Internal Auditors Research Foundation, Austin TX.

Bartlett, G.D., Kremin, J., Saunders, K.K. \& Wood, D.A. 2015. Attracting applicants for in-house and outsourced internal audit positions: Views from external auditors. Accounting Horizons 30(1): 143-56.

Blay, A. \& Geiger, M. 2013. Auditor fees and auditor independence: Evidence from going concern reporting decisions. Contemporary Accounting Research 30 (2): 579-606.

Barua, A., Rama, D.V. \& Sharma, V. 2010. Audit committee characteristics and investment in internal auditing. Journal of Accounting and Public Policy 29(5): 503-513. 
Basuony, M.A., Mohamed, E.K.A. \& Al-Baidhani, A.M. 2014. The effect of corporate governance on bank financial performance: Evidence from the Arabian Peninsula. Corporate Ownership \& Control 11(2): 178-191.

Berglund, N.R., Eshleman, J.D. \& Guo, P. 2018. Auditor size and going concern reporting. Auditing: A Journal of Practice \& Theory 37(2): 1-25.

Breger, D., Edmonds, M. \& Ortegren, M. 2020. Internal audit standard compliance, potentially competing duties, and external auditors' reliance decision. Journal of Corporate Accounting \& Finance 31(1): 112-124.

Bronson, S.N., Carcello, J.V., Hollingsworth, C.W. \& Neal, T.L. 2009. Are fully independent audit committees really necessary?. Journal of Accounting and Public Policy 28(4): 265-280.

Carey, P., Subramaniam, N. \& Ching, K.C.W. 2006. Internal audit outsourcing in Australia. Accounting \& Finance 46(1): 11-30.

Coelho, L., Serra, M., Ruben, M., Peixinho, T. \& Trijensen, S. 2012. Going concern opinions Are Not Bad News: Evidence From Industry Rivals. Social Science Research Network Electronic Paper Series.

Carcello, J.V., Hermanson, D.R. \& Huss, H. 2000. Going-concern opinions: The effects of partner compensation plans and client size. Auditing: A Journal of Practice \& Theory. 19 (1): 67-77.

Carcello, J.V., Hermanson, D.R. \& Raghunandan, K. 2005. Factors associated with US public companies' investment in internal auditing. Accounting Horizons 19(2): 69-84.

Carson, E., Fargher, N.L., Geiger, M., Lennox, C., Raghunandan, K. \& Willekens, M. 2013. Audit reporting for goingconcern uncertainty: A research synthesis. Auditing: A Journal of Practice \& Theory. 32 (Supplement): 353-384.

Chan, Y.K. \& Walter, T.S. 1996. Qualified audit reports and costly contracting. Asia Pacific Journal of Management 13(1): 37-63.

Čular, M., Slapničar, S. \& Vuko, T. 2020. The effect of internal auditors' engagement in risk management consulting on external auditors' reliance decision. European Accounting Review: 1-22.

Davidson, B.I., Desai, N.K. \& Gerard, G.J. 2013. The effect of continuous auditing on the relationship between internal audit sourcing and the external auditor's reliance on the internal audit function. Journal of Information Systems 27(1): 41-59.

Dopuch, N., Holthausen, R.W. \& Leftwich, R.W. 1987. Predicting audit qualifications with financial and market variables. The Accounting Review 62(3): 431-454.

Geiger, M.A. \& Rama, D.V. 2006. Audit firm size and going-concern reporting accuracy. Accounting Horizons, 20(March): $1-17$.

Goh, B.W., Krishnan, J. \& Li, D. 2013. Auditor reporting under Section 404: The association between the internal control and going concern audit opinions. Contemporary Accounting Research 30(3): 970-995.

Goodwin-Stewart, J. \& Kent, P. 2006. The use of internal audit by Australian companies. Managerial Auditing Journal 21(1): 81-101.

Gronewold, U. \& Heerlein, A. 2009. The staff capacity of the internal audit function of German corporations. Paper presented at midyear meeting of the auditing section of the American accounting association.

Hutchinson, M.R. \& Zain, M.M. 2009. Internal audit quality, audit committee independence, growth opportunities and firm performance. Corporate Ownership and Control 7(2): 50-63.

Iskandar, T.M., Rahmat, M.M., Noor, N.M., Saleh, N.M. \& Ali, M.J. 2011. Corporate governance and going concern problems: Evidence from Malaysia. International Journal of Corporate Governance 2(2): 119-139.

Ismael, H.R. \& Roberts, C. 2018. Factors affecting the voluntary use of internal audit: evidence from the UK. Managerial Auditing Journal 33: 288-317.

Lim, G.H. 1997. Audit qualification: What does it mean? Singapore Management Review19(2): 78-80.

Mutchler, J.F. 1985. A multivariate analysis of the auditor's going-concern opinion decision. Journal of Accounting Research 23(2): 668-682.

Narayanaswamy, R., Raghunandan, K. \& Rama, D.V. 2019. Internal auditing in India and China: some empirical evidence and issues for research. Journal of Accounting, Auditing \& Finance 34(4): 511-523.

NST. 2018. More listed firms facing distress? New Straits Times. Retrieved from https://www.nst.com.my /business/2018/09/407311/more-listed-firms-facing-distress.

Numan, W. \& Willekens, M. 2012. Competitive pressure, audit quality, and industry specialization. Working paper, KU Leuven.

Omer, W.K.H. \& Al-Qadasi, A.A. 2020. Board of directors' effectiveness and monitoring costs. Managerial Auditing Journal 35(4): 477-497.

Osman, M.N.H., Latiff, A.R.A., Daud, Z.M. \& Sori, Z.M. 2018. The impact of management, family, and institution on the auditor's going concern opinion issuance decision. International Journal of Economics and Management 12(2): 671-691.

Osman, M.N.H., Turmin, S.Z., Muhamad, H. \& Hussain, R. 2016. Auditor characteristics and the issuance of going concern opinion. International Business Management 10(17): 3733-5250.

Prawitt, D.F., Smith, J.L. \& Wood, D.A. 2009. Internal audit quality and earnings management. The Accounting Review 84(4): 1255-1280.

Raza, A., Hussin, W.N.W. \& Majid, J.A. 2019. Delisting of firms in Malaysia; what the financial conditions and auditor reports reveal?. Advances in Social Sciences Research Journal 6(5): 90-97. 
Wan-Hussin, W.N. \& Bamahros, H.M. 2013. Do investment in and the sourcing arrangement of the internal audit function affect audit delay? Journal of Contemporary Accounting \& Economics 9(1): 19-32.

Zmijewski, M.E. 1984. Methodological issues to the estimation of financial distress prediction models. Journal of Accounting Research. 22 (Suppl): 59-82.

\section{Fazlin Erwinaz Hassan}

Payroll Department

The Ministry of Defence

Jalan Padang Tembak, Kementah

50634 Kuala Lumpur

MALAYSIA.

E-mail: fazlinerwinazn9@gmail.com

\section{Amirul Hafiz Mohd Nasir*}

Centre for Governance Resilience and Accountability Studies

Faculty of Economics and Management

Universiti Kebangsaan Malaysia

43600 UKM Bangi, Selangor

MALAYSIA.

E-mail: amirul@ukm.edu.my

* Corresponding author 